\title{
Kebijakan Pemerintah Kabupaten Siak Terhadap Pemberdayaan Perempuan Sebagai Pemotong Getah Karet (Kajian di Kampung Teluk Merempan Kecamatan Mempura Kabupaten Siak)
}

\author{
Dessy Artina $^{1 *}$, Mexsasai Indra ${ }^{2}$, Muhammad A Rauf $^{3}$, Nur Ainun ${ }^{4}$ \\ 1, 2, 3, 4 Fakultas Hukum Universitas Riau, Pekanbaru, Indonesia \\ *E-mail:dessy.artina@lecturer.unri.ac.id
}

Dikirim: 19/10/2020

\begin{tabular}{l}
\hline Info Artikel \\
\hline Keywords: \\
Policy; Siak Regency \\
Government; Women \\
Empowermen. \\
\\
\\
Kata Kunci: \\
Pemberdayaan \\
Perempuan. \\
Siak; \\
\\
Kemerintah
\end{tabular}

Direvisi: 20/03/2021

Dipublikasi: 25/3/2021

\section{Abstract}

Indonesia is a constitutional state as stated in Article 1 Paragraph 3 of the 1945 Constitution and adheres to the concept of the rule of law. Indonesia is a democratic country that upholds the values of justice. Siak Regency is one of the districts in Riau Province which is synonymous with Malay culture. The values of local wisdom are still very thick in the life of the Malay people in Siak. The constitutional rights of citizens are regulated in the 1945 Constitution. In relation to fighting for constitutional rights, it cannot be denied that gender issues are an inhibiting factor for the development of society, especially for women. This is also an implication of the lack of system support that accommodates women in honing their potential and creativity, especially in rural areas. Therefore this paper is present as an emotional outpouring of questioning the role and involvement of women in the Merempan Hilir area to improve quality. family life through the agricultural sector built on the basis of rational arguments. The agricultural sector is the main sector that gets great attention and hope in rural communities and this agricultural sector is the main sector of livelihood for the people of the area. this is based on the characteristics of Indonesia as an archipelagic country which incidentally has an agrarian style, so that agricultural activities have become a tradition that is still well preserved today. However, the problem in the life of rural communities in general is the limited access to potential sources in an area. The type of research used is sociological legal research. This paper is the result of research made in the form of a final report and writing in this journal. 
DOI:

10.47268/sasi.v27i1.415

sistem yang mewadahi perempuan dalam mengasah potensi dan kreatifitas yang ada dalam dirinya, terutama di daerah-daerah perdesaan. Oleh karena itu tulisan ini hadir sebagai curahan emosional untuk mempertanyakan peran serta keterlibatan perempuan di daerah Merempan Hilir terhadap peningkatan kualitas hidup keluarga melalui sektor pertanian yang dibangun dalam basis argumentasi yang rasional. Sektor pertanian merupakan sektor utama yang mendapatkan perhatian dan harapan besar dalam masyarakat pedesaan dan sektor pertanian ini menjadi sektor utama mata pencaharian bagi masyarakat daerah tersebut. Ini didasari pada ciri khas Indonesia sebagai negara kepulauan yang notabenen masyarakatnya bercorak agraris, sehingga kegiatan pertanian menjadi tradisi yang masih terawat hingga saat ini. Problematika dalam kehidupan masyarakat pedesaan pada umumnya adalah keterbatasan terhadap rendahnya akses sumber-sumber potensial yang ada di suatu daerah. Jenis penelitian yang digunakan adalah penelitian hukum sosiologis. Tulisan ini merupakan hasil penelitian yang dibuat dalam bentuk laporan akhir dan tulisan pada jurnal ini.

\section{A. PENDAHULUAN}

Negara Indonesia adalah negara hukum berdasarkan ketentuan konstitusional dalam Pasal 1 ayat 3 Undang-Undang Dasar Negara Republik Indonesia Tahun 1945. Mengenai pengertian hukum menurut E. Utrecht sebagaimana dikutip Yulies Tiena Masriani mengemukakan bahwa "hukum adalah himpunan petunjuk hidup yang mengatur tata tertib dalam suatu masyarakat dan seharusnya ditaati oleh anggota masyarakat yang bersangkutan, karena pelanggaran terhadap petunjuk hidup itu dapat menimbulkan tindakan dari pemerintah masyarakat itu". ${ }^{1}$ Selanjutnya dikutip pendapat Immanuel Kant yang mengartikan hukum sebagai "keseluruhan syarat-syarat yang dengan ini kehendak bebas dari orang yang satu dapat menyesuaikan diri dengan kehendak bebas dari orang lain, menuruti peraturan hukum tentang kemerdekaan". ${ }^{2}$ Dari pendapat para sarjana tersebut dapat disimak bahwa hukum pada hakikatnya merupakan aturan atau norma yang mengatur tingkah laku masyarakat dalam pergaulan hidup yang disertai sanksi hukum atas pelanggaran norma bersangkutan. ${ }^{3}$

Pertanyaan yang sering kita dengarkan terkait dengan kapan tepatnya hukum mulai ada, hal itu tidak dapat diketahui. Berdasarkan pada ungkapan klasik yang menyebutkan " $u b i$ societas ibi ius" terjemahannya yaitu "dimana ada masyarakat disitu ada hukum"4 . Berdasarkan pada ungkapan klasik tersebut, dengan demikian pertanyaannya dapat digeser menjadi sejak kapan adanya masyarakat. Terhadap pertanyaan ini juga tidak ada jawaban yang pasti. Namun, secara historis tidak pernah dijumpai adanya manusia yang mampu hidup secara sendiri atau soliter, manusia tidak akan mampu menjalani kehidupannya secara individu. Hal tersebut tentunya idak dapat dipungkiri bahwa secara kodrati manusia memang merupakan makhluk bermasyarakat atau makhluk sosial. Begitupula dalam aspek kehidupan sosial, politik dan ekonomi.

Indonesia pada saat ini sedang menuju pada taraf kemajuan ekonomi yang cukup menggembirakan, kemajuan ekonomi bisa dirasakan oleh masyarakat dalam berbagai sektor kehidupan, baik sektor masyarakat desa, sektor masyarakat kota, dalam dan luar negeri. ${ }^{5}$ Meskipun tidak dapat dipungkiri pada saat tertentu, adakalanya perekonomian Indonesia

\footnotetext{
1 Masriani, Yulies Tiena. (2008). Pengantar Hukum Indonesia, Jakarta: Sinar Grafika, h. 6-7

2 Ibid, h.7

3 Ibid

4 Marzuki, Peter Mahmud. (2008). Pengantar Ilmu Hukum, Jakarta: Kencana Prenada Media Group, h. 41.

5 Dermawan, Abdurraafi Maududi. (2016). Pemberdayaan Perempuan Mellaui Ekonomi Kreatif,
} RAHEEMA: Jurnal Studi Gender dan Anak, 3 (2), 159-172. https://doi.org/10.24260/raheema.v3i2.569. 
mengalami penurunan, tetapi masyarakat Indonesia berusaha bangkit memperbaiki ekonominya, khususnya ekonomi keluarga. Akan tetapi, kemajuan ekonomi belum sepenuhnya dirasakan oleh kaum perempuan. Perempuan masih sangat tergantung pada ekonomi suaminya. Negara Indonesia merupakan negara demokrsi sebagaimana yang termaktub dalam pasal 1 ayat 2 Undang-Undang Dasar Negara Republik Indonesia Tahun 1945. Dalam negara demokrasi, percakapan warga negara seharusnya tidak terhenti dalam dimensi struktur sosial, baik itu atas dasar gender, ekonomi ataupun agama. Artinya seluruh identitas warga negara harus dianggap setara dalam bingkai negara hukum yang demokratis apalagi terhadap persoalan hak-hak warga negara yang dijamin oleh konstitusi, hal ini dilaksanakan agar percakapan warga negara tidak menimbulkan hierarki nilai dalam impelementasinya. Basis utama argumen ini tentunya berangkat dari Pasal $28 \mathrm{C}$ ayat 2 Undang-Undang Dasar Negara Republik Indonesia yang menjelaskan bahwa "Setiap orang berhak untuk memajukan dirinya secara kolektif untuk membangun masyarakat, bangsa dan negaranya. " Dalam kaitannya terhadap memperjuangkan hak konstitusional, tidak dapat dipungkiri isu gender menjadi faktor penghambat bagi perkembangan masyarakat, terutama bagi kaum perempuan. Hal ini juga implikasi dari ketiadaan dukungan sistem yang mewadahi perempuan dalam mengasah potensi dan kreatifitas yang ada dalam dirinya, terutama di daerah-daerah perdesaan. Oleh karena itu tulisan ini hadir sebagai curahan emosional untuk mempertanyakan peran serta keterlibatan perempuan di daerah Merempan Hilir terhadap peningkatan kualitas hidup keluarga melalui sektor pertanian yang dibangun dalam basis argumentasi yang rasional. Membincangkan persoalan yang terkait dengan perempuan, memang tidak pernah ada habisnya, permasalahan terkait dengan perempuan selalu menarik dan tidak akan pernah selesai. Hal ini karena kedudukan perempuan patut mendapatkan perhatian dalam setiap usaha dalam pembangunan suatu bangsa. Pemberdayan perempuan merupakan salah satu cara strategis untuk meningkatkan potensi perempuan dan meningkatkan peran perempuan baik di domain publik maupun domein domestik. ${ }^{6}$ Keberhasilan wanita ditunjang dari kelebihan-kelebihan wanita yang merupakan faktor dominan terhadap keberhasilannya sebagai pelaku usaha, baik bergerak di bidang swasta maupun bergerak di bidang pemerintahan. Seperti yang dikemukakan oleh Suryohadiprojo, kemampuan perempuan memang semakin kelihatan dalam berbagai pekerjaan dan profesi. ${ }^{7}$ Hampir tidak ada pekerjaan yang tidak bisa dikerjakan oleh perempuan seperti dikerjakan oleh laki-laki. Hampir semua bidang pekerjaan perempuan mampu untuk mengerjakannya juga, terkecuali yang berkaitan dengan pekerjaan yang memerlukan kekuatan fisik, seperti pekerjaan di pelabuhan, akan tetapi tidak bisa kita pungkiri juga bahwa, terkadang profesi yang kita anggap perempuan mustahil untuk melakukannya justru posisi tersebut juga ditempatkan oleh sebagian dari kaum perempuan.

Menurut Hubeis pemberdayaan perempuan adalah upaya memperbaiki status dan peran perempuan dalam pembangunan bangsa, sama halnya dengan kualitas peran dan kemandirian organisasi perempuan. ${ }^{8}$ Daulay menyampaikan bahwa program pemberdayaan perempuan di Indonesia pada hakikatnya telah dimulai sejak tahun 1978, dalam perkembangannya upaya dalam kerangka pemberdayaan perempuan ini secara kasat mata telah menghasilkan suatu proses peningkatan dalam berbagai hal. Seperti peningkatan dalam kondisi, derajat, dan kualitas hidup kaum perempuan di berbagai sektor strategis seperti bidang pendidikan, ketenagakerjaan, ekonomi, kesehatan dan pertanian atau perkebunan. Dewasa ini, yang menjadi permasalahan terkait dengan posisi perempuan di dalam masyarakat cenderung terdapat perbedaan perlakuan sikap maupun perbuatan terhadap kaum perempuan tersebut. Perempuan selalu dipandang

6 Zakiyah, (2010). Pemberdayaan Perempuan Oleh Lajnah Wanita dan Putri Al-Irsyad Surabaya. Analisa: Journal of Social Science and Religion, 17 (1), 37-56. https://doi.org/10.18784/analisa.v17i1.113

7 Lutfiyah. (2013). Pemberdayaan Wanita Berbasis Potensi Unggulan Lokal. SAWWA: Jurnal Studi Gender, 8 (2), 213-223. https://doi.org/10.21580/sa.v8i2.653.

8 Saugi, Wildan., \& Sumarno. (2015). Pemberdayaan Perempuan Melalui Pelatihan Pengolahan Bahan Pangan Lokal. Jurnal Pendidikan dan Pemberdayaan Masyarakat, $2 \quad$ (2), $226-238$. https://doi.org/10.21831/jppm.v2i2.6361

$$
\text { 75|S A S Vol. } 27 \text { No.1, Januari- Maret } 2021
$$


sebelah mata dan diposisikan pada posisi yang lemah dibandingkan dengan kaum laki-laki. Keterbatasan dalam pengetahuan serta adanya perbedaan antara laki-laki dengan perempuan semakin membuat parah kedudukan kaum perempuan di Indonesia, khususnya di daerah-daerah kecil atau daerah terpencil. Hal ini membuat perempuan tidak berdaya, misalnya dilihat dari segi adat yang berlaku dimasyarakat adat yakni, adat partilineal, matrilineal, dan bilateral, ${ }^{9}$ padahal dalam kesetaraan gender harus berasaskan kepada kemanusiaan dan keadilan, antara laki-laki dan perempuan harus sejajar dan tidak boleh ada perbedaan atau diskriminasi. ${ }^{10}$

Pada masyarakat Patrilineal seperti Suku Batak, Lampung, dan Flores, anak laki-laki akan menjadi pewaris seperti kepala keluarga pengganti ayah.Padahal perempuan dominan disana mencari nafkah dengan mengurus ladang, rumah serta pekerja lainnya. Dalam pengambilan keputusan perempuan tidak mempunyai hak memberikan saran maupun pendapat. Adapun dalam masyarakat bilateral, seperti di Jawa lebih pada menerima anak ragil atau paling kecil yang biasa menemani kedua orangtuanya. ${ }^{11}$ Persoalan yang di hadapi perempuan perlu mendapatkan solusi, yaitu berupa pemberdayaan. Menurut Undang-Undang Nomor 20 Tahun 2008 tentang prinsip, dan tujuan pemberdayaan, pemberdayaan bertujuan dalam rangka meningkatkan ekonomi kerakyatan agar dapat meningkatkan pendapatan dan kesejahteraan masyarakat serta memperluas lapangan pekerjaan untuk pengentasan rakyat dari permasalahan kemiskinan. $^{12}$

Konsep pemberdayaan merupakan suatu upaya untuk menjadikan sesuatu yang adil dan beradab menjadi lebih efektif dalam seluruh aspek kehidupan. Pemberdayaan menurut Dadang Juliantara dkk, pemberdayaan adalah upaya menjadikan suasana kemanusiaan yang adil dan beradab menjadi semakin efektif secara struktural baik di dalam kehidupan keluarga, masyarakat, negara, regional, internasional, maupun dalam bidang politik, ekonomi, dan lainlain. ${ }^{13}$

Pemberdayaan perempuan merupakan proses kesadaran dan pem-bentukan kapasitas (capacity building) terhadap partisipasi yang lebih besar untuk memiliki kekuasaan dan pengawasan dalam pembuatan keputusan dan transformasi (transformation action) agar perempuan mampu menghasil-kan sesuatu yang bermanfaat. Perempuan cenderung memiliki kemandirian apabila mempunyai pendapatan dan kegiatan ekonomi. ${ }^{14}$ Pendapatan menjadi menjadi faktor penting untuk perempuan agar memiliki kekuatan dalam posisi tawar dalam setiap pengambilan keputusan di rumah tangga dan di luar rumah tangga termasuk keputusan terkait dengan nasib perempuan itu sendiri. Pemberdayaan perempuan ternayata berperan penting terhadap kelangsungan hidup keluarga, baik berkenan dengan pembinaan moral anak, maupun pemenuhan kebutuhan ekonomi keluarga sebagai salah satu pilar utama berlangsungnya kehidupan keluarga. ${ }^{15}$ Penelitian terhadap pemberdayaan perempuan di Kampung Teluk Merempan sebagai pemotong getah atau karet menyebutkan bahwa dengan perempuan memiliki berpenghasilan sendiri perempuan menjadi sangat mandiri. sehingga

9 Sutisna, Anan. (2013). Model Pemberdayaan Perempuan dan Pengarustamaan Gender Melalui Layanan Pendidikan Masyarakat Pada Pusat Kegiatan Belajar Masyarakat. Cakawala Pendidikan, 32 (3), 470-479. https://doi.org/10.21831/cp.v3i3.1634.

${ }^{10}$ Ismail, Z., Lestari, M. P., Rahayu, P., \& Eleanora, F. N. (2020). Kesetaraan Gender Ditinjau dari Sudut Pandang Normatif dan Sosiologis. SASI, 26 (2), 154-161. https://doi.org/10.47268/sasi.v26i2.224, h. 154.

11 Sutisna, Anan. Op. Cit.

12 Fitrina, Nika Rizqi. (2016). Pemberdayaan Perempuan Dalam Meningkatkan Kesejahteraan Keluarga Melalui Industri Kecil di Pedesaan (Studi dalam Kelompok Usaha Bersama (KUB) Serang di Desa Pulorejo Kecamatan Purwodadi Kabupaten Grobogan, Skripsi: UNNES.

13 Khairunnisa, Iin. (2017). Pemberdayaan Ekonomi Perempuan di Daerah, Jurnal Ilmiah Ilmu Ekonomi, 6 (11), 81-91. http://eprints.ummi.ac.id/149.

14 Hasanah, Siti. (2013). Pemberdayaan Perempuan Melalui Kegiatan Ekonomi Berkeadilan (Simpan Pinjam Syariah Perempuan), SAWWA: Jurnal Studi Gender, 9 (1), https://doi.org/10.21580/sa.v9i1.666

15 Tjiptaningsih,Wahyu. (2017). Pemberdayaan Perempuan Dalam Upaya Peningkatan Ekonomi Keluarga (Studi Kasus Pada Kelompok Usaha Perempuan di Desa Sindangkempeng Kecamatan Greged Kabupaten Cirebon), REFORMASI: Jurnal Ilmiah Administrasi, 2 (1), 28-35, http://dx.doi.org/10.33603/reformasi.

$$
\text { 76|S A S Vol. } 27 \text { No.1, Januari - Maret } 2021
$$


perempuan memiliki keberanian untuk mengambil keputusan secara mandiri. Selain itu, pada saat ini akses perempuan di berbagai bidang belum memenuhi akses keadilan. ${ }^{16}$ Perempuan harus mendapatkan kesempatan dan peluang yang sama dalam berbagai aspek kehidupan, khususnya dalam bidang pekerjaan, agar perempuan mampu berdayaguna secara baik dikehidupan masyarakat.

Pemberdayaan perempuan ternyata berperan penting terhadap kelangsungan hidup keluarga, baik berkenaan dengan pembinaan moral anak, maupun pemenuhan kebutuhan ekonomi keluarga sebagai salah satu pilar utama berlangsungnya kehidupan keluarga. ${ }^{17}$ Berkaitan dengan hal tersebut menunjukkan bahwa kaum perempuan sudah banyak terlibat dalam segala bidang kehidupan, baik di bidang ekonomi, politik, sosial dan budaya. Khususnya di bidang ekonomi banyak dijumpai pada dewasa ini perempuan yang bekerja/berkarir. Misalnya di Kampung Teluk Merempan Kabupaten Siak, jumlah petani karet perempuan lebih banyak dibandingkan dengan jumlah petani laki-laki. Sekitar $70 \%$ Jumlah petani didominasi oleh perempuan.

Sektor pertanian merupakan sektor utama yang mendapatkan perhatian dan harapan besar dalam masyarakat pedesaan dan sektor pertanian ini menjadi sektor utama mata pencaharian bagi masyarakat daerah tersebut. hal ini didasari pada ciri khas Indonesia sebagai negara kepulauan yang notabenen masyarakatnya bercorak agraris, sehingga kegiatan pertanian menjadi tradisi yang masih terawat hingga saat ini. Namun problematika dalam kehidupan masyarakat pedesaan pada umumnya adalah keterbatasan terhadap rendahnya akses sumbersumber potensial yang ada di suatu daerah. sehingga pembangunan daerah sebagai mercusuar awal juga terhambat.

Disisi lain dalam pemikiran ilmiah Islam, persoalan wanita perlu di gali untuk mengaktifkan keterlibatan wanita dalam pembangunan. Dengan perkembangan zaman, tentu saja peran wanita sebagai ibu rumah tangga mengalami pergeseran dimensional sehingga perlu ada keseimbangan antara urusan rumah tangga dengan pekerjaan diluar rumah, terlebih lagi dengan keadaan kondisi ekonomi yang terjadi pada dewasa ini, tidak dapat kita nafikkan bahwa perempuan atau seorang istri terpaksa bekerja untuk membantu suami untuk memenuhi kebutuhan sehari-hari dan tentunya hal tersebut membuat kita tidak bisa menutup mata terhadap realita yang ada bahwa kadang-kadang istripun dituntut untuk mampu juga berperan sebagai pencari nafkah. ${ }^{18}$ Lain dari pada itu menurut Dillon ${ }^{19}$ pembangunan merupakan usaha pemerdekaan diri yang bertahap, yang menitikberatkan usaha pada suatu tahapan yang benar yaitu "growth through equity atau (pertumbuhan melalui keadilan sosial) yang sangat relevan apabila diterapkan dengan situasi saat ini. Jalan pikirannya adalah menjadikan keadilan sebagai pemilik mayoritas di negeri ini, terutama bagi para petani. Sehingga dalam hal ini perempuan perlu mendapatkan keadilan dalam bentuk pengembangan diri melalui profesi yang ia miliki, seperti pendidikan dan pelatihan memotong getah karet di Merempan Hilir Kabupaten Siak.

Berangkat dari hal tersebut pemberdayaan masyarakat pada dasarnya merupakan strategi perubahan sosial secara terencana yang ditujukan untuk mengatasi masalah atau memenuhi kebutuhan masyarakat. Dalam proses pemberdayaan, masyarakat mendapatkan pembelajaran agar dapat secara mandiri melakukan upaya-upaya perbaikan terhadap kualitas kehidupannya. Dengan demikian, proses tersebut harus dilaksanakan dengan adanya keterlibatan penuh masyarakat itu sendiri secara bertahap, terus-menerus, dan berkelanjutan.

Pemberdayaan masyarakat dilakukan di Kampung Teluk Merempan Kecamatan Mempura Kabupaten Siak, mata pencarian masyarakat sebagian besar adalah petani, terutama

16 Fitri, Ria. (2010). Pemberdayaan Perempuan Dalam Penyelenggaraan Otonomi Daerah. KANUN: Jurnal Ilmu Hukum, 12 (2), 349-366. http://www.jurnal.unsyiah.ac.id/kanun/article/view/6300.

17 Tjiptaningsih, Wahyu. Op. Cit.

18 Amelia, Euis. (2009). Keadilan Distributif Dalam Ekonomi Islam, Jakarta: Raja Wali Press, h. 353.

19 Soedarmanta, J. B. (2012). An Indonesian Renaissance kebangkitan kembali republik perspektif Dillon. Jakarta: Kompas Media Nusantara, h. 145.

$$
\text { 77|SASI Vo1. } 27 \text { No.1, Januari-Maret } 2021
$$


perempuan. Perempuan ikut serta dalam membantu perekonomian keluarga, seperti membantu perekonomian keluarga dengan bekerja sebagai pemotong getah karet. Adanya peran perempuan yang ikut serta dalam membantu perekonomian keluarga inilah yang menjadi menarik. Peran perempuan pada umumnya yaitu hanya melakukan pekerjaan domestik saja, seperti mengurus suami dan anak, memasak, dan mengerjakan pekerjaan rumah tangga lainnya. Tetapi disisi lain perempuan dengan kondisi-kondisi yang disebutkan sebelumnya harus mampu bekerja tanpa melupakan kodratnya sebagai perempuan. Oleh karena itu, perempuan harus ditumbuhkan rasa kesadaran akan potensi yang dimilikinya. Potensi tersebut dapat dijadikan bentuk usaha yang dapat menghasilkan pendapatan keluarga guna membantu perekonomian keluaga, sehingga perempuan tidak perlu bekerja di sector formal atau mencari pekerjaan di luar, cukup dengan menggali potensi dan memanfaatkan sumber yang ada. Dengan demikian, perempuan dapat menjadikan potensi dan sumber yang ada sebagai peluang untuk menghasilkan pendapatan keluarga guna membantu perekonomian keluarga. Namun tidak jarang perempuan menemukan kesulitan dalam membantu perekonomian keluarga. Perempuan masih banyak yang merasa kurang percaya diri dan belum sadar akan potensi yang ia miliki. Ditambah lagi dengan tidak dibekali pengetahuan, keterampilan, dan modal membuat perempuan tidak dapat menjalankan peran untuk ikut serta dalam membantu perekonomian keluarga. Disisi lain, ruang gerak perempuan pun semakin sempit sebab struktur sosial dan arus kultural yang masih menempatkan kaum perempuan dibawah kaum laki-laki hal tersebut yang membuat kaum perempuan menjadi semakin sulit untuk mengembangkan potensi yang dimiliki. ${ }^{20}$

Pendapatan pas-pasan yang dihasilkan oleh kepala keluarga (suami), mendorong para perempuan untuk berperan aktif dalam membantu pendapatan ekonomi keluarga. Persoalan yang dihadapi perempuan dari golongan berpenghasilan rendah pada khususnya, timbul karena ada kaitanya dengan status sebagai perempuan, sehingga perlu mendapatkan perhatian dalam rangka meningkatkan partisipasi perempuan melalui proses pembangunan sosial ekonomi. ${ }^{21}$ Perhatian tersebut juga dapat diimplementasikan instrumen-instrumen hukum berupa aturan yang memberikan ruang bagi penyediaan pelatihan dan pendidikan bagi petani desa yang notabenennya perempuan untuk mengembangkan potensi yang mereka miliki. Oleh karena itu urgensi dari tulisan ini ialah meninjau pemberdayaan perempuan melalui kebijakan yang dikeluarkan oleh Pemerintah setempat untuk mewujudkan kesejahteraan dan kesetaraan sosial bagi masyarakat, khususnya di Kampung Teluk Merempan Kabupaten Siak.

Secara geografis Kampung Teluk Merempan merupakan salah satu desa di Kecamatan Mempura. Terbentuknya Kecamatan Mempura sebagai institusi eksekutif yang berperan menjalankan roda pemerintahan dan pemberdayaan serta pembangunan masyarakat merupakan perpanjangan tangan dari pemerintah otonomi Kecamatan Mempura, merupakan aspirasi masyarakat yang bermanfaat yang bertujuan agar dapat memberikan kemudahan atau mempermudah masyarakat dalam konteks pelaksanaan kepengurusan dibidang administrasi serta memberikan dampak positif hubungan antara pemerintah dengan rakyat nya agar menjadi lebih dekat. Pemerintah Kecamatan Mempura yang sebelumnya merupakan bagian dari Kecamatan Siak yang kemudian terpisah menjadi wilayah Kecamatan di Kecamatan Mempura. Dengan demikian potensi yang ada di Kecamatan ini secara tidak langsung lebih terangkat dengan jangkauan pemerintah yang lebih dekat, jangkauan pembangunan yang lebih baik dibandingkan dengan pemerintah yang lama. Adapun Kecamatan Mempura yang posisi pusat pemerintahannya terletak di Benteng Hilir, juga merupakan pusat pemerintahan Kecamatan Mempura itu sendiri ${ }^{22}$

20 Putri, O. N., Darwis, R. S., \& Basar, Gigin Ginanjar K. 2015). Pemberdayaan Perempuan Kepala Keluarga, Prosiding Ks: Riset \& Pkm, 2 (2), 147 - 300, https://doi.org/10.24198/jppm.v2i2.13538, h. 280.

21 Sajogyo., \& Sajogyo, Pudjiwati. 2007). Sosiologi Pedesaan, Yogyakarta: Gadjah Mada University Press, h. 78 .

${ }^{22}$ http://paten.siakkab.go.id/mempura/index.php?com=halutama\&link=data informasi diakses 5 Februari 78|S A S V Vol. 27 No.1, Januari- Maret 2021 
Sebagian besar dari petani di Kampung Teluk Merempan merupakan petani karet, pekerjaannya bukan hanya menunjang kehidupan keluarga tapi sumber utama mata pencarian, sehingga pemerintah dalam pemberdayaan perempuan di Kampung Teluk Merempan harus memprioritaskan hal ini. Perempuan merupakan potensi dan aset daerah yang memiliki peranan dalam peningkatan kesejahteraan umum. Pemerintah daerah atau pemerintah desa perlu memberikan perhatian serius untuk memberdayakan perempuan di daerah melalui pelibatan secara langsung maupun tidak langsung perempuan di daerah dalam proses kebijakan pembangunan di desa atau daerah. Pemberdayaan dan peningkatan kualitas sumber daya manusia khususnya perempuan desa sangat mungkin dilakukan melalui berbagai kegiatan guna memberdayakan mereka secara ekonomi, sosial, politik, dan psikologis. ${ }^{23}$

\section{B. METODE PENELITIAN}

Jenis penelitian yang digunakan dalam penelitian ini adalah yuridis empiris atau penelitian hukum sosiologis. Penelitian yuridis empiris adalah penelitian yang dilakukan dengan cara mengadakan identifikasi hukum dan bagaimana efektifitas hukum itu berlaku dalam masyarakat. ${ }^{24}$ Sedangkan sifat penelitiannya dapat digolongkan kepada penelitian yang bersifat deskriptif, karena dalam penelitian ini peneliti mengadakan penelitian langsung pada lokasi atau tempat yang diteliti bertujuan untuk memperoleh gambaran secara jelas dan lengkap tentang suatu keadaan atau masalah yang diteliti. Penelitian dilakukan di Dinas Pemberdayaan Perempuan dan Perlindungan Anak Kabupaten Siak, Dinas Pertanian dan Perkebunan Kabupaten Siak, di Kepenghuluan Teluk Merempan.

\section{PEMBAHASAN}

\section{Kebijakan Pemerintah Kabupaten Siak terhadap pemberdayaan perempuan sebagai pemotong getah karet (Kajian di Kampung Teluk Merempan Kecamatan Mempura Kabupaten Siak}

Urusan pemberdayaan perempuan dan perlindungan anak saat ini berada di bawah Kementerian Pemberdayaan Perempuan dan Perlindungan Anak (Kementerian PP dan PA), yakni kementerian yang mempunyai tugas menyelenggarakan urusan di bidang pemberdayaan perempuan dan perilndungan anak dalam pemerintahan untuk membantu Presiden dalam menyelenggarakan pemerintahan negara dengan fungsinya sebagai berikut $:^{25}$

a) Perumusan dan penetapan kebijakan di bidang pemberdayaan perempuan dan perlindungan anak.

b) Koordinasi dan sinkronisasi pelaksanaan kebijakan di bidang pemberdayaan perempuan dan perlindungan anak.

c) Pengelolaan barang milik kekayaan negara yang menjadi tanggungjawab Kementerian Pemberdayaan Perempuan dan Perlindungan Anak.

d) Pengawasan atas pelaksanaan tugas di lingkungan Kementerian pemberdayaan perempuan dan perlindungan anak.

Salah satu urusan pemerintahan Kementerian Pemberdayaan Perempuan dan Perlindungan Anak terdapat dalam lampiran Undang-Undang Nomor 23 Tahun 2014 Tentang

2020

23 Rosdiana, Weni. (2015). Analisis Pemberdayaan Perempuan Desa (Studi di Desa Bulutengger Kecamatan Sekaran Kabupaten Lamongan). Jurnal Kebijakan \& Manajemen Publik, 3 (2), 117-131. https://doi.org/10.21070/jkmp.v3i2.187.

24 Al-Banjary, Syaifurrahman. (2005). Hitam Putih Polisi dalam Mengungkap jaringan Narkoba, Jakarta: Restu Agung dan Ptik Press, h. 17.

${ }^{25}$ Kusriyah, Sri. (2017). Kebijakan Pemerintah Daerah Dalam Pemberdayaan Perempuan di Kabupaten Demak, Jurnal Pembaharuan Hukum, 4 (1), 120-129. http://dx.doi.org/10.26532/jph.v4i1.1651. 
Pemerintahan Daerah terkait dengan pembagian urusan pemerintahan antara pusat, provinsi, dan kabupaten dalam urusan pemberdayaan perempuan dan perlindungan anak dalam sub urusan kualitas hidup perempuan, yang menjadi urusan pemerintah daerah : a) Pelembagaan pengarustamaan gender (PUG) pada lembaga pemerintah tingkat daerah Kabupaten/Kota, b) pemberdayaan perempuan bidang politik, hukum, sosial, dan ekonomi pada organisasi kemasyarakatan tingkat kabupaten/kota. c) penguatan dan pengembangan lembaga penyedia layanan pemberdayaan perempuan tingkat Kabupaten/Kota. ${ }^{26}$

Berdasarkan hasil wawancara dengan Kepala Dinas Pemberdayaan Perempuan Kabupaten Siak, bahwa pemerintah daerah mempunyai program-program terkait dengan gender, semua dinas instansi yang terdapat di Kabupaten Siak selalu melibatkan perempuan dalam setiap kegiatan. Pemerintah daerah dan dewan perwakilan rakyat daerah (DPRD) Kabupaten siak sangat mendukung terhadap program-program gender tersebut. ${ }^{27}$

Terkait dengan bidang pertanian, Kabupaten Siak belum memiliki MOU, akan tetapi sudah ada program kegiatan untuk hal tersebut. Ada pelatihan-pelatihan, kerajinan-kerajinan yang dibuat oleh pemerintah daerah siak itu sendiri untuk mengembangkan potensi dan kemampuan yang dimiliki oleh kaum perempuan yang ada di Siak. Adapun kelemahan yang dialami oleh Pemerintah daerah Siak yaitu pada bidang pemasaran. Inilah yang menjadi kendala utama yang dialami oleh Pemerintah Daerah Siak dalam kegiatan atau program yang dilakukan di daerah. Hal ini tentunya harus adanya koordinasi antara instansi-instansi terkait dalam hal untuk melaksanakan setiap kegiatan atau program yang dilakukan oleh pemerintah daerah setempat, misalnya koordinasi dengan dinas pertanian, perkebunan, perindustrian dan dinas terkait lainnya.

Berdasarkan hasil wawancara dengan Bapak Muhammad Ihsan Kepala Bidang Perkebunan Kabupaten Siak, bahwa terkait dengan pemberdayaan perempuan sebagai pemotong getah atau karet di Kabupaten Siak yang berkaitan dengan kebijakan atau programprogram khusus tentang perempuan tersebut belum ada. Selain hal tersebut ini juga berkaitan dengan potensi yang dimiliki oleh daerah. Pada saat ini pemerintah daerah Kabupaten Siak lebih mengorientasikan di bidang Sawit, hal ini dikarenakan jangka waktu yang dibutuhkan untuk menghasilkan karet tersebut lebih lama dibandingkan dengan sawit dan harga jual sawit lebih tinggi dari pada karet. Oleh karena itu, pemerintah daerah Kabupaten Siak lebih memfokuskan pada program atau bantuan untuk petani sawit.$^{28}$

Dalam hal pekerjaan tentunya perempuan lebih telaten dibandingkan dengan laki-laki. Dengan ketelatenan yang dimiliki perempuan tersebut tentunya ini akan berdampak pada produk yang dihasilkan. Pemerintah daerah siak khsusunya dinas pemberdayaan perempuan memiliki tupoksi yaitu pemberdayaan dan perlindungan. Adanya surat edaran yang dibuat oleh Dinas Pemberdayaan Perempuan, bahwa semua kegiatan harus responsif gender. Hal ini tentunya bertujuan untuk melindungi serta memberdayakan perempuan.

Kebijakan Pemerintah Kabupaten Siak terhadap perempuan sebagai pemotong getah atau karet di Kampung Teluk Merempan belum ada. Padahal pada umumnya yang bekerja sebagai pemotong karet lebih dominan kaum perempuan. Tentunya ini menjadi permasalahan yang harus diatasi oleh pemerintah daerah Kabupaten Siak, agar perempuan sebagai pemotong karet hak-hak nya dapat dilindungi dan diberikan oleh pemerintah daerah Siak. Pada saat adanya pelatihan-pelatihan yang dilakukan oleh Pemerintah Daerah Siak yang sering dilibatkan yaitu laki-laki, padahal sesungguhnya yang bekerja sebagai pemotong getah atau karet itu lebih banyak dari kalangan ibu-ibu.

26 Ibid

27 Wawancara dengan Bapak Kepala Dinas Pemberdayaan perempuan (Bapak Darussalim ) tanggal 14 Oktober 2020

28 Wawancara dengan Bapak Kepala Bidang Perkebunan Kabupaten Siak ( Bapak Muhammad Ihsan ) tanggal 19 Oktober 2020

$$
\text { 80|S A S Vol. } 27 \text { No.1, Januari-Maret } 2021
$$


Berdasarkan hasil wawancara dengan Kepala Kampung Teluk Merempan, bahwa belum ada bantuan atau program dari pemerintah untuk perempuan di daerah Merempan. Biasanya pemerintah daerah lebih memprioritaskan pada bidang peternakan. Adapun yang menakik dari kaum ibu-ibu di Teluk Merempan itu sendiri berkisaran 60-70\% dari kaum perempuan. Ada yang memiliki kebun sendiri, akan tetapi rata-rata mayoritas kebun orang lain yang kebanyakan dimiliki oleh keturunan Tiongha. Terkait dengan program dibidang pertanian itu dilakukan oleh Desa dan anggaran juga didapatkan dari Anggaran desa. 30\% anggaran tersebut diberikan untuk perempuan, dikarenakan di desa diprioritaskan pada bidang pemberdayaan perempuan. Di desa ini biasanya nya program-program yang dilakukan dalam bentuk kegiatan. Teluk Merempan juga telah memiliki Badan Usaha Milik Desa (BUMDES), jadi, jika masyarakat tidak mampu membuka usaha atau memerlukan modal maka masyarakat dapat meminjam ke BUMDES untuk membuka usaha tersebut dan hanya dibayar dalam bentuk angsuran. ${ }^{29}$

Pogram pemerintah daerah lebih dominan pada sawit, dikarenakan sawit hanya memerlukan waktu 3 tahun menjelang dipanen, sedangkan karet itu memerlukan waktu lebih kurang 6 tahun. Jadi, pemerintah daerah lebih memprioritaskan pada sawit. Di Kampung Teluk Merempan memiliki rencana untuk membuat tanaman tumpang sari, misalnya Keladi Bening, yang mana Keladi Bening ini dalam waktu 3 bulan sudah dapat menghasilkan dan program ini melibatkan kaum perempuan.

Berdasarkan hasil wawancara dengan para pemotong karet Kampung Teluk Merempan, bahwa belum ada bantuan yang diberikan oleh pemerintah daerah di bidang pertanian, khususnya para petani pemotong karet atau getah. Para petani mengalami permasalahan terkait dengan anggaran dan harga karet yang tidak menentu. Terkadang harga karet sangat murah, dan kadang tinggi. Sebelumnya harga karet mencapai 7000/ kg akan tetapi karena kondisi hujan, para petani karet tersebut tidak dapat melalukan aktifitas menakik atau menyadap karet tersebut

Para petani Perempuan atau pemotong getah daerah Teluk Merempan ini menginginkan adanya perhatian dari pemerintah daerah agar dapat mengembangkan atau membantu mereka dalam bekerja. Karena mayoritas perempuan di Teluk Merempan ini bekerja sebagai pemotong getah atau karet sebagai mata pencahariannya. ${ }^{30}$

\section{Kebijakan ideal terkait pemberdayaan perempuan sebagai pemotong getah karet (Kajian di Kampung Teluk Merempan Kecamatan Mempura Kabupaten Siak)}

Adapun kebijakan ideal terkait pemberdayaan perempuan sebagai pemotong getah karet di Kampung Teluk Merempan adalah diharapkan bahwa pemerintah daerah kabupaten Siak khususnya untuk membuat kebijakan yang berkaitan dengan perlindungan terhadap perempuan dalam berbagai aspek, khususnya yang bekerja sebagai pemotong getah karet di Teluk Merempan. Pemerintah daerah setempat harus melindungi hak-hak mereka sebagai warga negara serta memberikan pelatihan-pelatihan ataupun kegiatan lainnya yang berguna untuk mengembangkan potensi yang ada dalam diri perempuan itu sendiri. Pemerintah harus lebih memperhatikan hak-hak kaum perempuan serta melalukan pemberdayaan terhadap perempuan dalam berbagai aspek. Pada dewasa ini, tidak dapat dipungkiri bahwa perempuan memiliki peran sentral dalam membantu perekonomian keluarga. Banyak dijumpai bahwa di era modernisasi ini perempuan menjadi tulang punggung keluarga ketika suami nya sudah tidak ada atau bercerai, bahkan perempuan sebagai wanita karir merupakan hal yang tidak tabu lagi kita jumpai dalam masyarakat. Dikarenakan tuntutan ekonomi, terkadang peran suami sebagai kepala keluarga tidak mencukupi kebutuhan hidup keluarga tertentu, sehingga hal demikian menimbulkan perempuan harus bekerja untuk membantu suami dalam memenuhi kebutuhan hidupnya. Di kampung Teluk Merempan perempuan yang bekerja sebagai pemotong getah atau

29 Wawancara dengan Kepala Kampung Teluk Merempan (Bapak Suhendrizal, tanggal 16 Oktober 2020

30 Wawancara dengan petani perempuan pemotong getah atau Karet Teluk Merempan, tanggal 19 Oktober 
karet berkisar sekitar 30\%, sehingga hal tersebut harus mendapat perhatian khusus dari pemerintah setempat agar hak-hak mereka dapat dilindungi.

Pemerintah Kabupaten Siak juga harus saling bersinergi satu sama lain agar kebijakankebijakan yang hendak dibuat mampu terealisasi dengan baik. Dengan adanya kebijakankebijakan yang pro terhadap perempuan yang berkaitan dengan pemberdayaan perempuan, maka kedepannya nilai-nilai keadilan akan terwujud serta memberikan peluang atau kesempatan yang sama terhadap perempuan.

Selain itu diharapkan juga terkait dengan pemberdayaan perempuan sebagai pemotong getah karet di Teluk Merempan ini lebih diperhatikan oleh pemerintah setempat, dengan memberikan pelatihan-pelatihan yang tidak hanya didominasi oleh kaum laki-laki, akan tetapi juga di prioritaskan bagi kaum perempuan, karena pada faktanya jumlah perempuan sebagai penakik atau pemotong getah karet di Teluk Merempan lebih banyak dibandingkan dengan lakilaki. Pemberdayaan perempuan ini bertujuan agar perempuan mendapatkan kesempatan dan perlakuan yang sama dari negara. Yang mana perempuan ini identik dengan salah satu golongan yang rentan terhadap pelanggaran HAM, oleh karena itu, pemerintah, baik pemerintah pusat ataupun pemerintah daerah melakukan perlindungan terhadap kaum perempuan serta membuat kebijakan-kebijakan yang pro terhadap kaum perempuan. Dalam hal ini terkait dengan kebijakan pemerintah daerah Siak terhadap pekerjaan perempuan sebagai pemotong getah atau karet di Kampung Teluk Merempan, Kecamatan Mempura Kabupaten Siak. Sebagai penunjang ekonomi keluarga, tentunya perempuan dituntut untuk bisa membantu suami dalam memenuhi kebutuhan ekonomi keluarga, dan tidak jarang pula kita bisa melihat secara langsung dilapangan, bahwa banyak perempuan yang juga bekerja, baik di pemerintahan,ataupun bekerja secara individu dalam bentuk membuka usaha dan memanfaatkan sumber daya alam yang ada.

\section{P E N U T U P}

Berdasarkan pembahasan diatas maka dapat disimpulkan bahwa adapun kesimpulan yang dapat diambil pada penelitian diatas adalah Bahwa Kebijakan Pemerintah Kabupaten Siak terhadap pemberdayaan perempuan sebagai pemotong getah karet di Teluk Merempan belum ada, baik itu dalam bentuk kebijakan atau program- program kegiatan.

Kedepannya diharapkan pemerintah daerah Kabupaten Siak lebih memperhatikan para petani perempuan yang bekerja sebagai pemotong getah karet di Kampung Teluk Merempan khususnya dan diseluruh Kabuparen Siak secara umumnya, agar melindungi serta memberikan hak-hak mereka. Serta menyiapkan anggaran dan pelatihan-pelatihan untuk kaum perempuan serta melakukan pemberdayaan terhadap perempuan dari berbagai aspek (Ekonomi, sosial, dan budaya) dan khususnya bagi petani perempuan

\section{DAFTAR PUSTAKA}

\section{Jurnal}

[1] Amelia, Euis. (2009). Keadilan Distributif Dalam Ekonomi Islam, Jakarta: Raja Wali Press.

[2] Dermawan, Abdurraafi Maududi. (2016). Pemberdayaan Perempuan Mellaui Ekonomi Kreatif, RAHEEMA: Jurnal Studi Gender dan Anak, 3 (2), 159-172. https://doi.org/10.24260/raheema.v3i2.569.

[3] Fitri, Ria. (2010). Pemberdayaan Perempuan Dalam Penyelenggaraan Otonomi Daerah. KANUN: Jurnal Ilmu Hukum, 12 (2), 349-366. http://www.jurnal.unsyiah.ac.id/kanun/article/view/6300.

[4] Hasanah, Siti. (2013). Pemberdayaan Perempuan Melalui Kegiatan Ekonomi Berkeadilan (Simpan Pinjam Syariah Perempuan), SAWWA: Jurnal Studi Gender, 9 (1), https://doi.org/10.21580/sa.v9i1.666.

$$
\text { 82|SASI Vol. } 27 \text { No.1, Januari-Maret } 2021
$$


[5] Ismail, Z., Lestari, M. P., Rahayu, P., \& Eleanora, F. N. (2020). Kesetaraan Gender Ditinjau dari Sudut Pandang Normatif dan Sosiologis. SASI, 26 (2), 154-161. https://doi.org/10.47268/sasi.v26i2.224.

[6] Kusriyah, Sri. (2017). Kebijakan Pemerintah Daerah Dalam Pemberdayaan Perempuan di Kabupaten Demak, Jurnal Pembaharuan Hukum, 4 (1), 120129. http://dx.doi.org/10.26532/jph.v4i1.1651.

[7] Khairunnisa, Iin. (2017). Pemberdayaan Ekonomi Perempuan di Daerah, Jurnal Ilmiah Ilmu Ekonomi, 6 (11), 81-91. http://eprints.ummi.ac.id/149.

[8] Lutfiyah. (2013). Pemberdayaan Wanita Berbasis Potensi Unggulan Lokal. SAWWA: Jurnal Studi Gender, 8 (2), 213-223. https://doi.org/10.21580/sa.v8i2.653.

[9] Putri, O. N., Darwis, R. S., \& Basar, Gigin Ginanjar K. 2015). Pemberdayaan Perempuan Kepala Keluarga, Prosiding Ks: Riset \& Pkm, 2 (2), $147 \quad$ - 300, https://doi.org/10.24198/jppm.v2i2.13538.

[10]Rosdiana, Weni. (2015). Analisis Pemberdayaan Perempuan Desa (Studi di Desa Bulutengger Kecamatan Sekaran Kabupaten Lamongan). Jurnal Kebijakan \& Manajemen Publik, 3 (2), 117-131. https://doi.org/10.21070/jkmp.v3i2.187.

[11] Sutisna, Anan. (2013). Model Pemberdayaan Perempuan dan Pengarustamaan Gender Melalui Layanan Pendidikan Masyarakat Pada Pusat Kegiatan Belajar Masyarakat. Cakawala Pendidikan, 32 (3), 470-479. https://doi.org/10.21831/cp.v3i3.1634.

[12] Saugi, Wildan., \& Sumarno. (2015). Pemberdayaan Perempuan Melalui Pelatihan Pengolahan Bahan Pangan Lokal. Jurnal Pendidikan dan Pemberdayaan Masyarakat, 2 (2), 226-238. https://doi.org/10.21831/jppm.v2i2.6361.

[13] Tjiptaningsih,Wahyu. (2017). Pemberdayaan Perempuan Dalam Upaya Peningkatan Ekonomi Keluarga (Studi Kasus Pada Kelompok Usaha Perempuan di Desa Sindangkempeng Kecamatan Greged Kabupaten Cirebon), REFORMASI: Jurnal Ilmiah Administrasi, 2 (1), 28-35, http://dx.doi.org/10.33603/reformasi.

[14]Zakiyah, (2010). Pemberdayaan Perempuan Oleh Lajnah Wanita dan Putri Al-Irsyad Surabaya. Analisa: Journal of Social Science and Religion, 17 (1), 37-56. https://doi.org/10.18784/analisa.v17i1.113.

\section{Buku}

[15]Al-Banjary, Syaifurrahman. (2005). Hitam Putih Polisi dalam Mengungkap jaringan Narkoba, Jakarta: Restu Agung dan Ptik Press.

[16] Masriani, Yulies Tiena. (2008). Pengantar Hukum Indonesia, Jakarta: Sinar Grafika.

[17] Marzuki, Peter Mahmud. (2008). Pengantar Ilmu Hukum, Jakarta: Kencana Prenada Media Group.

[18] Sajogyo., \& Sajogyo, Pudjiwati. 2007). Sosiologi Pedesaan, Yogyakarta: Gadjah Mada University Press.

[19] Soedarmanta, J. B. (2012). An Indonesian Renaissance Kebangkitan Kembali Republik Perspektif Dillon. Jakarta: Kompas Media Nusantara.

\section{Skripsi, Online/World Wide Web}

[20]Fitrina, Nika Rizqi. (2016). Pemberdayaan Perempuan Dalam Meningkatkan Kesejahteraan Keluarga Melalui Industri Kecil di Pedesaan (Studi dalam Kelompok Usaha Bersama (KUB) Serang di Desa Pulorejo Kecamatan Purwodadi Kabupaten Grobogan, Skripsi: UNNES.

[21] http://paten.siakkab.go.id/mempura/index.php?com=halutama\&link=data_informasi. 